\title{
Research methods for animal models of atherosclerosis (Review)
}

\author{
YALI ZHANG ${ }^{1,2}$, MAHREEN FATIMA $^{1,2}$, SIYUAN HOU $^{2}$, LIANG BAI $^{1,2}$, SIHAI ZHAO $^{1,2}$ and ENQI LIU ${ }^{1,2}$ \\ ${ }^{1}$ Research Institute of Atherosclerotic Disease, Xi'an Jiaotong University Cardiovascular Research Centre; \\ ${ }^{2}$ Laboratory Animal Center, Xi'an Jiaotong University Health Science Centre, Xi'an, Shaanxi 710061, P.R. China
}

Received February 25, 2021; Accepted May 20, 2021

DOI: $10.3892 / \mathrm{mmr} .2021 .12511$

\begin{abstract}
Atherosclerosis is a chronic inflammatory disease that threatens human health and lives by causing vascular stenosis and plaque rupture. Various animal models have been employed for elucidating the pathogenesis, drug development and treatment validation studies for atherosclerosis. To the best of our knowledge, the species used for atherosclerosis research include mice, rats, hamsters, rabbits, pigs, dogs, non-human primates and birds, among which the most commonly used ones are mice and rabbits. Notably, apolipoprotein E knockout (KO) or low-density lipoprotein receptor $\mathrm{KO}$ mice have been the most widely used animal models for atherosclerosis research since the late 20th century. Although the aforementioned animal models can form atherosclerotic lesions, they cannot completely simulate those in humans with respect to lesion location, lesion composition, lipoprotein composition and physiological structure. Hence, an appropriate animal model needs to be selected according to the research purpose. Additionally, it is necessary for atherosclerosis research to include quantitative analysis results of atherosclerotic lesion size and plaque composition. Laboratory animals can provide not only experimental tissues for in vivo studies but also cells needed for in vitro experiments. The present
\end{abstract}

Correspondence to: Professor Enqi Liu, Research Institute of Atherosclerotic Disease, Xi'an Jiaotong University Cardiovascular Research Centre, 76 Yanta West Road, Xi'an, Shaanxi 710061, P.R. China

E-mail: liuenqi@xjtu.edu.cn

Abbreviations: LDL, low-density lipoprotein; HFHC, high-fat/high-cholesterol; GM, genetically modified; KO, knockout; ApoE, apolipoprotein E; LDLR, low-density lipoprotein receptor; PCSK9, proprotein convertase subtilisin/kexin type 9; AAV, adeno-associated virus; ES, embryonic stem; VLDL, very low-density lipoprotein; HDL, high-density lipoprotein; CETP, cholesterol ester transfer protein; Fbn1, fibrillin-1; WHHL, Watanabe heritable hyperlipidemic; H\&E, hematoxylin-eosin; CT, computed tomography; MRI, magnetic resonance imaging; PET, positron emission computed tomography; HUVECs, Human umbilical vein endothelial cells; CRISPR/Cas9, clustered regularly interspaced short palindromic repeats-associated protein 9

Key words: atherosclerosis, animal model, mice, rabbit, cell culture review first summarizes the common animal models and their practical applications, followed by focus on mouse and rabbit models and elucidating the methods to quantify atherosclerotic lesions. Finally, the methods of culturing endothelial cells, macrophages and smooth muscle cells were elucidated in detail and the experiments involved in atherosclerosis research were discussed.

\section{Contents}

1. Introduction

2. Mice

3. Rabbits

4. Practical methods of using mice in atherosclerosis research

5. Practical methods of using rabbits in atherosclerosis research

6. Noninvasive imaging of animal model in atherosclerosis

7. In vitro study of atherosclerosis

8. Conclusion

\section{Introduction}

Atherosclerosis is characterized by the hardening and narrowing of arterial lumen, due to fatty deposits called plaques that form on the inner walls of arteries (1). It is responsible for most cardiovascular diseases such as coronary artery disease, stroke and peripheral vascular disease. However, the exact cause of atherosclerosis remains controversial. From pathological perspectives, atherosclerosis has been defined as a chronic inflammatory disease involved in endothelial cell dysfunction, lipid infiltration, macrophage recruitment and vascular smooth muscle cells migration (2). Vascular endothelial cells become dysfunctional under the stimulation of several factors, such as mechanical stress and oxidative stress $(3,4)$. The modified lipid in blood enters the endothelial layer and stimulates endothelial cells to release chemokines and adhesion molecules, which recruits monocytes in blood to migrate into the intima and transform into macrophages (5). Macrophages phagocytose lipids cholesterol by CD36 or scavenger receptor. Excessive lipid accumulation transforms macrophage to foam cells (6). Necrotic foam cells aggregate to form the lipid-rich necrotic core of plaques. In addition, activated macrophages release inflammatory factors and chemokines, which can promote the proliferation and migration of smooth muscle cells in the 
media layer to intima (7). Smooth muscle cells, macrophages and extracellular matrix make up the fibrous cap. The lesions continue to develop and eventually form plaques. Vascular endothelial dysfunction is considered as an early marker for atherosclerosis (8). In humans, atherosclerosis often occurs in the bifurcation or bending of artery, where turbulence is prone to occur. This may result from continuous shear stress leading to vascular endothelial cell dysfunction. In addition, oxidative stress is also the main cause of endothelial dysfunction (3). In turn, endothelial cell dysfunction can produce more reactive oxygen species (ROS) and aggravate oxidative stress (9). Oxidative stress can promote inflammation and increase the modified lipoproteins (10). Oxidized low density lipoprotein (ox LDL) has been shown to aggravate atherosclerosis through a variety of ways, such as aggravating vascular inflammation and form cell formation (11). In vivo, dyslipidemia, characterized by high triglyceride and lipid cholesterol, can aggravate inflammation and atherosclerosis (12). Activated inflammation recruits more macrophages to the injured blood vessel. The aggregation of macrophages intensified the process of lipid phagocytosis, inflammatory mediators release, foam cell formation and atherosclerosis exacerbation. Fig. 1 shows the association between lipid abnormality, oxidative stress, endothelial dysfunction and inflammation in the development of atherosclerosis. High levels of low-density lipoprotein (LDL) cholesterol, as well as inflammation, smoking, hypertension and diabetes, have been shown to be risk factors of atherosclerosis (13-17). Currently, atherosclerosis is mainly treated by altering lifestyle, taking statin medications and undergoing surgeries.

Despite considerable advances in the treatment of cardiovascular diseases, it remains the leading cause of mortality and morbidity worldwide (18). The main challenge in atherosclerosis research is that evident clinical manifestations usually occur after decades, and the arterial wall changes profoundly during the development and progression of the disease. There is limited direct access to tissues from the different evolving stages of atherosclerosis for research because the vascular tissues obtained from individuals are under traumatic circumstances, such as warfare or automobile accidents (19-22). Studies have shown that atherosclerosis can occur in several animals, and this has made it possible to obtain tissues at all stages of atherosclerosis and cells needed for in vitro studies. Therefore, animal models of atherosclerosis have the potential to solve the problems of inherent restrictions in human research.

Indeed, animal models of atherosclerosis, over the past decades, have greatly increased the understanding on this chronic inflammatory disease and for assessing novel pharmacological treatments that can prevent or slow down the onset of atherosclerosis. The first animal model to be used for atherosclerosis research was rabbit, developed by Ignatowski, who demonstrated lesion formation in the aortic wall of rabbits that were fed animal protein-enriched diet (mainly meat, milk and egg yolk) (23). Since, various animal species, such as mice, rats, guinea pigs, hamsters, birds, dogs and non-human primates, have been used as experimental models for atherosclerosis (24). The following are considered as the essential requirements for developing animal models of atherosclerosis: i) Atherosclerotic lesions should be easily induced; ii) lesions should mimic those in humans; iii) lesions should have clinical sequelae; and iv) lesions should develop spontaneously after the consumption of a diet similar to that of humans.

The advantages and limitations of commonly used animal models are described briefly in Table I. Among these animal models, non-human primates closely resemble the human model of atherosclerosis, followed by pigs or dogs, based on anatomy, physiology, lipoprotein profile and site of lesion formation; however, they are less widely used owing to long feeding cycles and high costs (24). Mice are the most commonly used species, followed by rabbits, because of the following advantages: Ease of maintenance and breeding; genetic and transgenic pliability; and the rapid formation of atherosclerotic lesions. With the development in research, an increasing number of mice and rabbit strains have been bred, and advanced methods have been developed to provide further insights into atherosclerosis $(25,26)$. Moreover, appropriate lesion analysis is necessary to decrease experimental variability and, thereby, increase accuracy. The present review discusses the characteristics of atherosclerosis in different mouse and rabbit models and describes lesion analysis and cell culture methods used in atherosclerosis-associated research.

\section{Mice}

History of mice as atherosclerosis animal models. The use of micefor atherosclerosis research started in the late 1960s. Various research groups have attempted to clarify the plasma lipoprotein metabolism and susceptibility to atherosclerosis in mice. Vesselinovitch et al (27) and Vesselinovitch and Wissler (28) used closed-colony mice, called CF1, to induce atheroma in the aorta of the mice; however, the results were inconsistent even when the most atherogenic diet was used, because different animals showed different manifestations after being fed with the diet for similar duration. As the work was almost invariably performed on random-bred animals, it can be assumed that a high genetic variability must exist between individual animals in any one experiment $(27,28)$. Thompson (29) hypothesized that the genotype of animals is important in the development of atheroma by inducing atherosclerosis in inbred strain mice (C57BL/6) through a high-fat/high-cholesterol (HFHC) diet and found that atherosclerosis was observed in all mice after 25 weeks of HFHC diet treatment. Thompson concluded that all the C57BL/6 mice showed lesions in the aortic valve region (29). In the past 20 years from the study by Thompson (29), mice have been used as a favorable system for a combined genetic and biochemical analysis of atherosclerosis and lipoprotein metabolism. In 1985, Paigen et al (30) found that C57BL/6 mice were the most susceptible to development of diet-induced atherosclerosis among the ten inbred strains examined. Based on this original finding, it has become a common practice to perform atherosclerosis studies on C57BL/6 inbred strain mice, and this includes studies using genetically modified (GM) mice, despite the fact that in several instances this required founder GM mice to be continually backcrossed with the C57BL/6 strain. In the early 1990s, mouse models exhibiting very high cholesterol levels and relatively advanced lesions were created through genetic engineering, including apolipoprotein E knockout $(\mathrm{KO})\left(\mathrm{ApoE}^{-/}\right)$and $\mathrm{LDL}$ receptor $\mathrm{KO}\left(\mathrm{LDLR}^{--}\right)$ mice (31-33). Shortly afterwards, ApoE/LDLR double-KO mice with more severe hyperlipidemia and atherosclerosis 
Table I. Advantages and limitations of the widely used animal species for atherosclerosis research.

\begin{tabular}{|c|c|c|c|}
\hline Species & Advantages & Limitations & Common application \\
\hline Mice & $\begin{array}{l}\text { Explicit genomic information; easy } \\
\text { gene manipulation; low cost; easy } \\
\text { breeding; inbred strain }\end{array}$ & $\begin{array}{l}\text { Lipoprotein metabolism differs from } \\
\text { that of humans; plaque location differs } \\
\text { from that of humans; limited animal } \\
\text { samples for study; difficulty in } \\
\text { coronary artery research }\end{array}$ & $\begin{array}{l}\text { Exploring gene function; } \\
\text { studies on specific cell } \\
\text { types; signal pathway } \\
\text { studies }\end{array}$ \\
\hline Rabbits & $\begin{array}{l}\text { Spontaneous plaque formation; express } \\
\text { CETP; easy breeding; allow monitoring } \\
\text { of lesions by ultrasound or MRI }\end{array}$ & $\begin{array}{l}\text { Inbred rabbits not easily obtained; } \\
\text { limited gene modification; deficient } \\
\text { in hepatic lipase }\end{array}$ & Pharmacological study \\
\hline $\begin{array}{l}\text { Non-human } \\
\text { primates }\end{array}$ & $\begin{array}{l}\text { Simulate human pathological process } \\
\text { maximally; non-invasive imaging is } \\
\text { possible }\end{array}$ & $\begin{array}{l}\text { Expensive; ethical and welfare issues; } \\
\text { long modeling time }\end{array}$ & $\begin{array}{l}\text { Pharmacological study; } \\
\text { social and behavioral } \\
\text { study }\end{array}$ \\
\hline Pigs or dogs & $\begin{array}{l}\text { Lipid profile similar to that of humans; } \\
\text { plaque location close to that in humans; } \\
\text { non-invasive imaging is possible }\end{array}$ & $\begin{array}{l}\text { Limited gene modification; expensive } \\
\text { feeding costs }\end{array}$ & $\begin{array}{l}\text { Continuous observation } \\
\text { of lesions }\end{array}$ \\
\hline
\end{tabular}

CETP, cholesterol ester transfer protein; MRI, magnetic resonance imaging.

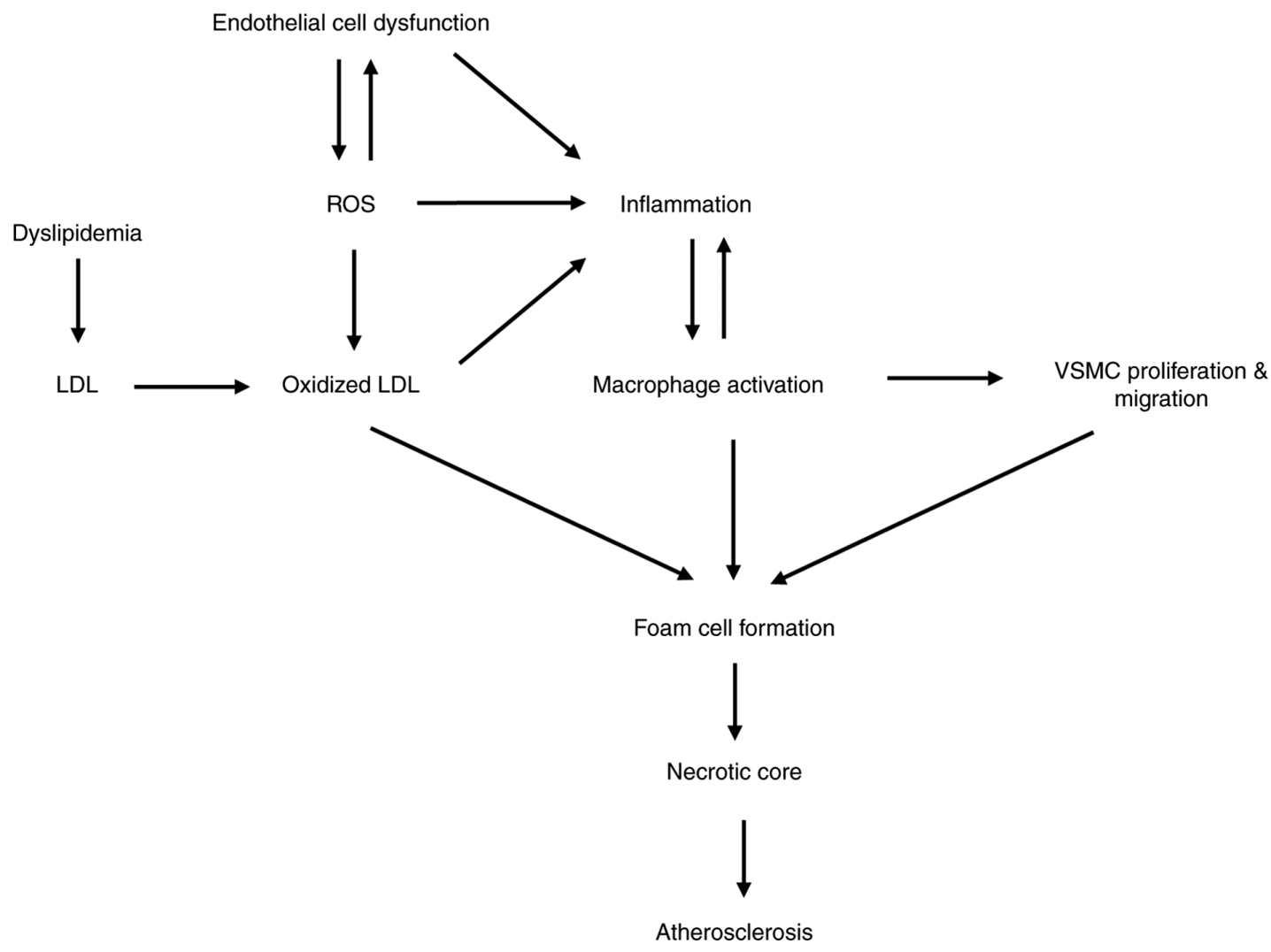

Figure 1. Association between dyslipidemia, oxidative stress, endothelial dysfunction and inflammation in the progress of atherosclerosis. LDL, low-density lipoprotein; ROS, reactive oxygen species; VSMC, vascular smooth muscle cell.

were developed $(34,35)$. Moreover, ApoE* 3-Leiden transgenic mice and SRB-1-1/ApoE ${ }^{-/}$mice have also been used in various studies (36-38). Recently, the proprotein convertase subtilisin/kexin type 9 (PCSK9)-adeno-associated virus (AAV) mice have been used as a rapid, versatile and cost-effective animal model for atherosclerosis research (39). The following section will focus on the characteristics of $\mathrm{ApoE}^{-1-}, \mathrm{LDLR}^{-1}$, PCSK9-AAV mice and other GM mouse models used in atherosclerosis research.

ApoE $E^{-/}$mice. The most extensively used mouse model of atherosclerosis is $\mathrm{ApoE}^{-/ /}$mice, which was developed in 1992 
using gene targeting technique in mouse embryonic stem (ES) cells to inactivate the endogenous Apoe gene $(32,33)$. ApoE is a glycoprotein, with a molecular size of $\sim 34 \mathrm{kDa}$, that serves as a ligand for cell-surface lipoprotein receptors and clears chylomicrons and very low-density lipoprotein (VLDL) remnants (40). Additionally, ApoE is involved in other functions, including cholesterol homeostasis, local redistribution of cholesterol within tissues, immunoregulation, dietary absorption and biliary excretion of cholesterol (41). Deletion of the Apoe gene impaired the ability to clear plasma lipoproteins, resulting in plasma cholesterol levels to reach $400-600 \mathrm{mg} / \mathrm{dl}$ mostly in the VLDL and chylomicron remnant fractions upon feeding a normal diet, whereas the plasma cholesterol levels in wild-type mice were estimated to be $75-110 \mathrm{mg} / \mathrm{dl}(42,43)$. Upon administration of a chow diet, the $\mathrm{ApoE}^{-/-}$mice were first observed to develop foam cell lesions at 10 weeks, followed by fatty streaks in the proximal aorta at 12 weeks, intermediate lesions containing foam cells and smooth muscle cells at 15 weeks, and fibrous plaques at 20 weeks of age (43). In highly advanced lesions, fibro-fatty nodules are a nidus for calcification and plaques become increasingly calcified with time (44). Moreover, a western diet (for example, consisting of $21 \%$ fat and $0.15 \%$ cholesterol) can accelerate the atherosclerotic process (45). Therefore, the western diet-fed $\mathrm{ApoE}^{-/-}$mice showed total plasma cholesterol concentration reaching $>1,000 \mathrm{mg} / \mathrm{dl}$ and the formation of more foam cell-rich atherosclerotic lesions containing cholesterol crystals, necrotic cores and calcifications (46).

The western diet-fed ApoE ${ }^{-/-}$mice can develop severe atherosclerosis in a short duration (12-16 weeks) and have become a favorable animal model for atherosclerosis research. Various studies on investigating the function of genes involved in developing atherosclerosis have been conducted on $\mathrm{ApoE}^{-/}$ mice (47). For instance, western diet-fed $\mathrm{ApoE}^{-/-}$mice lacking SR-A or CD36 demonstrated decreased lipid accumulation in peritoneal macrophages under in vivo conditions, and this effect was associated with increased areas of aortic sinus lesion, which is in contrast with the results of previous studies performed on C57BL/6 mice (48).

$L D L R^{-/}$mice. $\mathrm{LDLR}^{-/}$mice are another commonly used animal model for atherosclerosis research. LDLR is a membrane receptor that mediates the endocytosis of cholesterol-rich LDL and to clear LDL in the liver (49). In 1993, similar to the method used in $\mathrm{ApoE}^{-/-}$mice generation, $\mathrm{LDLR}^{-/-}$mice were created by homologous recombination in ES cells (31). Chow diet-fed $\mathrm{LDLR}^{-/}$mice displayed modestly elevated plasma cholesterol levels (200-300 mg/dl) and developed no or only mild atherosclerosis, even at an advanced age $(50,51)$. In terms of lipoprotein particles, the levels of intermediate-density lipoprotein and LDL-sized particles were increased, whereas the levels of high-density lipoprotein (HDL) and triglycerides remained unaffected $(31,50)$. The western diet-fed $L_{D L R}{ }^{-/}$mice showed accumulation of larger VLDL remnants with elevated total plasma cholesterol concentrations of $>1,000 \mathrm{mg} / \mathrm{dl}$ and the formation of mostly foamy lesions (52).

In 1997, researchers suggested that when the bone marrow from wild-type mice and $\mathrm{LDLR}^{-/}$mice were transplanted into irradiated $\mathrm{LDLR}^{-/}$mice, the two groups showed similar lesions, indicating that LDLR expressed by bone marrow cells had no effect on the lesions $(53,54)$. Thus, bone marrow transplantation is used as a tool to replace endogenous bone marrow-derived cells in the artery wall with those of the donor origin. This method is applicable for studying the effect of genes in white blood cells, for instance, the bone marrow transplantation from $\mathrm{LDLR}^{+/+} \mathrm{GM}$ mice into irradiated $\mathrm{LDLR}^{-/-}$mice provided a background of hyperlipidemia in the study of target genes. Of note, in this method, $\mathrm{LDLR}^{-/}$mice are not recommended to be replaced by ApoE ${ }^{-/-}$mice, because macrophage-derived ApoE has an independent role in lesion development $(55,56)$.

PCSK9-AAV mice. PCSK9-AAV mice were a new line of mouse models for atherosclerosis research created by two groups $(57,58)$. One of the best advantages of these mice is that atherosclerotic lesions can be formed by injecting AAV, without performing gene manipulation in animals. PCSK9 is an enzyme encoded by the PCSK 9 gene in humans on chromosome 1 . It binds with the LDL receptor, which blocks the ingestion of LDL-particles from extracellular fluid into cells. Following a single intravenous injection of human D374Y (57) or murine D377Y (58) gain-of-function mutant PCSK9, mice stably expressed Pcsk $9^{D Y}$ mRNA in the liver. Compared with control mice, the total serum cholesterol level in PCSK9DY-AAV transgenic mice was doubled after 30 days to 1 year of the injection (57). The western diet-fed PCSK9DY-AAV mice showed exacerbated hyperlipidemia with total cholesterol levels up to $1,165 \mathrm{mg} / \mathrm{dl}$ and the formation of lesions throughout the vasculature. Aortic root lesions showed advanced plaque development, with the presence of foam cells and smooth muscle cells in addition to macrophage infiltration and fibrous tissue formation (57,58). Moreover, lesions progressed to the fibro-atheromatous stage, and vascular calcification occurred within $15-20$ weeks $(59,60)$.

Other GM mice models. In addition to the aforementioned models, some emerging GM mice have been used in atherosclerosis research. For example, the SR-BI-/ApoER61(h/h) mice were generated by Zhang et al in 2005 (61) and were characterized by the development of diet-induced occlusive coronary atherosclerosis and myocardial infarction, compensating for the flaw that atherosclerotic plaques in mice are not prone to rupture. ApoE* 3-Leiden GM mice carrying the ApoE3-Leiden gene could develop severe hypercholesterolemia when fed an HFHC diet, exhibiting a more humanized form of lipoprotein cholesterol distribution system when crossbred with the human cholesterol ester transfer protein (CETP)-encoding transgenic mice $(62,63)$. CETP expression in ApoE3-Leiden mice shifts the distribution of cholesterol from HDL to VLDL/LDL, which resembles the cholesterol profile of humans (64). ApoE ${ }^{-/}-\mathrm{Fbn}^{1 \mathrm{C} 1039 \mathrm{G}+/-}$ mouse is an $\mathrm{ApoE}^{-/-}$mouse model with a mutation (C1039G+/-) in the fibrillin-1 (Fbnl) gene, which is characterized by the formation of vulnerable atherosclerotic plaques that are prone to rupture (65). Therefore, $\mathrm{ApoE}^{-/-} \mathrm{Fbn} 1^{\mathrm{C} 1039 \mathrm{G}+/}$ mouse can be used to study the features of unstable human plaques (66).

As a model of atherosclerosis research, mice have several advantages; however, they also have some limitations that cannot be ignored. Firstly, lipid metabolism in mice is very different from that in humans. The lipids present in the plasma of mice are mainly HDL, whereas those in humans are mainly 
LDL and VLDL. Moreover, natural CETP is absent in mice. Secondly, although atherosclerotic lesions tend to occur in disturbed blood flow regions in both humans and mice, the primary sites of lesion in mice are the aorta and carotids. Thirdly, mouse models rarely show evidence of lesion rupture, whereas in humans most of the mortality due to atherosclerosis results from plaque rupture.

\section{Rabbits}

Rabbit is the first developed and commonly used animal model for atherosclerosis research. The first report of diet-induced atherosclerosis in rabbits was provided by Ignatowski in 1908 (23). A few years later, in 1913, Anitschkow and Chalatows fed rabbits with cholesterol purified from egg and found that rabbits with atherosclerosis exhibited cholesterol accumulation in their livers (67). This was the first study to propose the role of cholesterol alone in inducing atherosclerosis. Subsequently, increasing research suggested that rabbits are an appropriate model for studying atherosclerosis because they easily develop atherosclerotic lesions when fed an HFHC diet, can be easily handled and require relatively inexpensive maintenance. Moreover, rabbits transport considerable amounts of cholesterol via ApoB-containing particles (VLDL and LDL) and express CETP, which is similar to that in humans. When compared with mice, the larger size of rabbits can provide some advantages such as noninvasive arterial analysis, providing sufficient arterial tissues and atherosclerotic lesions for harvest and enabling implantation of stents for biomechanical or pharmaceutical designing and testing. Currently, there are three types of rabbit models commonly used in atherosclerosis research: i) Cholesterol-fed rabbits; ii) GM rabbits; and iii) Watanabe heritable hyperlipidemic (WHHL) rabbits.

Cholesterol-fed rabbits. The normal range of plasma cholesterol in rabbits is $30-90 \mathrm{mg} / \mathrm{dl}$ at the age of 3-16 months, but it can increase up to $1,000 \mathrm{mg} / \mathrm{dl}$ following the administration of $0.3-0.5 \%$ cholesterol-enricheddiet.Additionally,supplementing the diet with $1-1.5 \%$ cholesterol for $\sim 8$ weeks increases the plasma cholesterol levels to 1,500-3,000 mg/dl (68). Monocyte adhesion to intimal endothelial cells and migration of monocytes into the subintima of the aorta could be observed under a microscope after high-cholesterol diet treatment. Lesion morphology is determined by the percentage of cholesterol added to the diet and the duration of the diet. Aortic lesions could be clearly visualized after feeding the rabbits with cholesterol diet for $\sim 6$ weeks (69). Additionally, coronary atherosclerosis was observed in cholesterol-fed rabbits but was usually restricted to the left coronary arterial trunk (69). Depending on the duration of cholesterol diet treatment, plaque calcification can occur. However, there is no evidence of spontaneous plaque rupture in these rabbits.

GM rabbits. GM rabbits have been reported as a model for studying cardiovascular diseases since 1994. To date, dozens of GM rabbits have been developed, including $\mathrm{ApoE}^{-/-}$rabbits and various transgenic rabbit strains $(70,71)$. Moreover, GM rabbit strains expressing nearly a dozen proteins involved in atherogenesis have been established in the laboratory, including those for human ApoAII, human ApoCIII, human CETP, endothelial lipase, MMP9 and human UII (72-77). Thus, these models provided insights into the molecular mechanisms involved in lipoprotein metabolism and function in atherosclerosis.

WHHL rabbits. The WHHL rabbits were developed by Watanabe (78), Kobe University, and exhibit familial hypercholesterolemia due to LDLR deficiency. The most popular of these studies were those confirming the hypothesis of the LDLR pathway formulated by Goldstein and Brown and elucidating the effects of statins on lowering the blood lipid levels (79). Moreover, after selective breeding, the coronary plaques changed to thin-cap fibroatheromas, and myocardial infarction developed spontaneously, which was rarely observed in other animal models (80). Interestingly, high-fructose and high-fat diet-fed WHHL rabbits developed early insulin resistance and glucose tolerance and showed aortic lesions with a lipid core and calcification (81). Therefore, this model has allowed researchers to investigate the effect of insulin resistance on atherosclerotic lesion formation. However, WHHL rabbits are less widely used, owing to the availability of few suppliers and breeding difficulties.

\section{Practical methods of using mice in atherosclerosis re- search}

The commonly used mice were obtained from the Jackson Laboratory and Charles River Laboratories. However, during research, more complex GM mouse models could provide insights into the mechanisms of atherosclerosis. A common method is to backcross a specific $\mathrm{KO}$ or transgenic mouse with $\mathrm{ApoE}^{-/}$or $\mathrm{LDLR}^{-/}$mice, thereby obtaining a double-KO/transgenic mouse model with a condition of hyperlipidemia for studying target gene function in atherosclerosis. Moreover, PCSK9-AAV injection is an alternative method for obtaining transgenic mouse models.

With the advancements in research, tissue-specific GM mice are increasingly used, most of which can be obtained through Cre-loxP recombination. Cre-loxP recombination is an approach through which the mice carrying the LoxP-flanked gene are crossbred with the mice carrying the Cre transgene, which is driven by a specific promoter to obtain tissue or cell-specific genetic manipulations. Tissue-specific gene $\mathrm{KO}$ mice can be obtained and then crossed with $\mathrm{ApoE}^{-/}$ or $\mathrm{LDLR}^{-/}$mice for atherosclerosis research (25).

Furthermore, choosing an appropriate diet for animal models is an important part, as it induces atherosclerosis. There is no doubt that western diet is most commonly used in atherosclerosis research since the 1990s. In general, a western diet containing $21 \%$ milk fat and $0.15 \%$ or $0.2 \%$ cholesterol is recommended (52), which approximately mimics the daily diet in western countries. Various studies have shown that there is a positive association between total plasma cholesterol levels and the extent of aortic lesion formed upon consuming different diets $(32,82,83)$. The cholesterol in this diet majorly consists of a proatherogenic agent. According to a previous research, the cholesterol content in all diet fed to mouse models of atherosclerosis was estimated to be $1.25 \%$ at most, owing to the toxicity of high doses of cholesterol feed (52). 


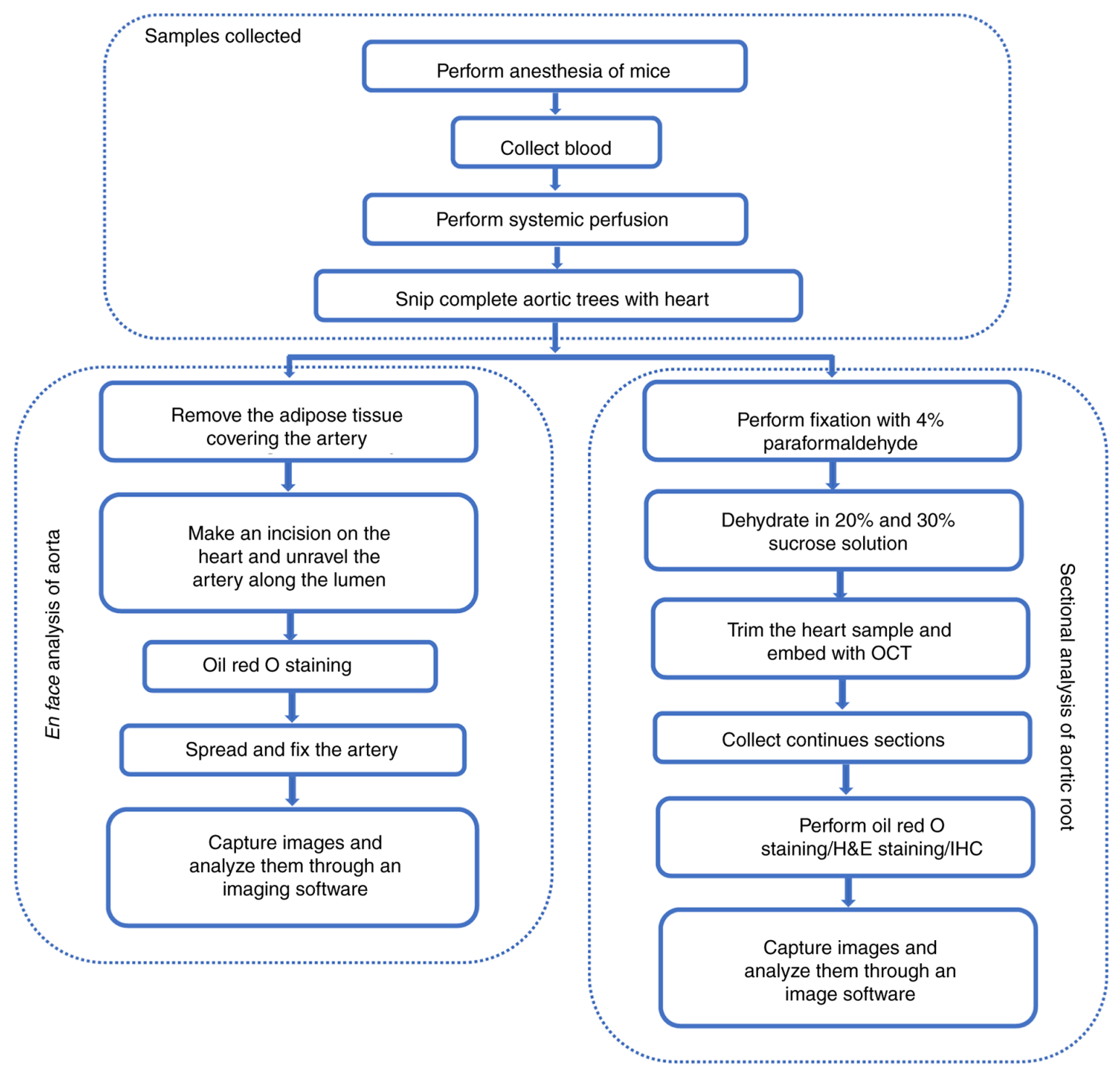

Figure 2. Procedure of atherosclerotic lesion quantification in mice. OCT, optimal cutting temperature; H\&E, hematoxylin-eosin; IHC, immunohistochemistry.

For general atherosclerotic models, HFHC diet is provided for 12-16 weeks; however, a sustained HFHC diet is likely to aggravate atherosclerotic lesion formation. The concentration of lipids present in blood, including total cholesterol, triglycerides, HDL-cholesterol and LDL-cholesterol, should be measured every 2 or 4 weeks while feeding an HFHC diet (84).

Fig. 2 elucidates the methods used for quantitative analysis of the pathological atherosclerotic lesions formed in mice: i) Aortic root cross-section; and ii) en face analysis of the aorta, 'aortic tree,' including whole aorta, aortic arch, thoracic artery, abdominal artery and left/right common carotid artery. Aortic roots are the most common region for the quantification of atherosclerotic lesions, as the lesions are stably observed in these areas. The lesions in the aortic roots vary with the location and size of plaques; therefore, it is necessary to cut continuous sections throughout the aortic root. The detailed procedure has been provided by Daugherty et al, Lin et al and Centa et al $(24,84,85)$. Briefly, the procedure for obtaining frozen sections of the embedded heart containing the aortic root and observing tissue staining is simple. In particular, $7-\mu \mathrm{m}$ thick sections are used, and the complete aortic root is collected through creating 60 sections for each sample. Ten consecutive sections were sequentially distributed in the same position on 10 numbered slides, starting from the appearance of a complete tricuspid valve, until each slide had six tissue sections. Slides with the same number were used for statistical analysis of plaque area and plaque composition. The thinner the section, the easier it is to accurately observe components in the plaque, since the components are spatially distributed in the plaque, but through immunostaining, the distribution of the target component could be observed in a plane. The sections were then stained with oil red $\mathrm{O}$ stain to assess the severity of atherosclerosis. The remaining frozen sections of aortic roots can be used to analyze the distribution and proportion of cells, such as smooth muscle cells and macrophages in plaques. The staining results of these sections were reported in previous studies $(84,86-88)$. The other commonly used method is to determine the size of the lesions in the aortic tree. This approach was introduced after the advent of GM animals, because the lesions in early atherosclerosis mice model were found only in the aortic roots. Therefore, this assessment method is relatively convenient. The aortic 
A

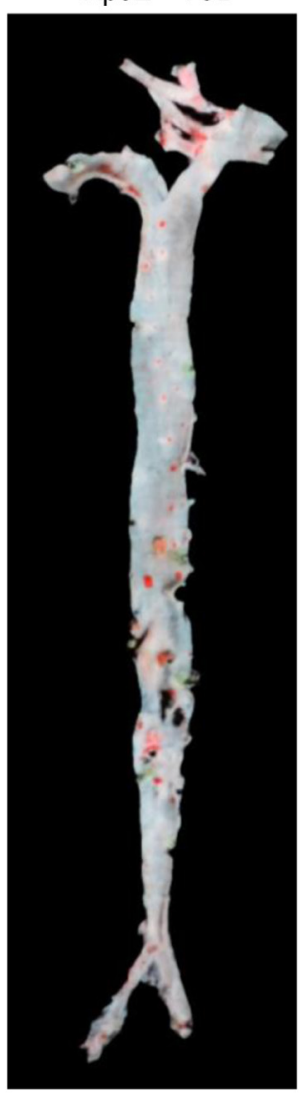

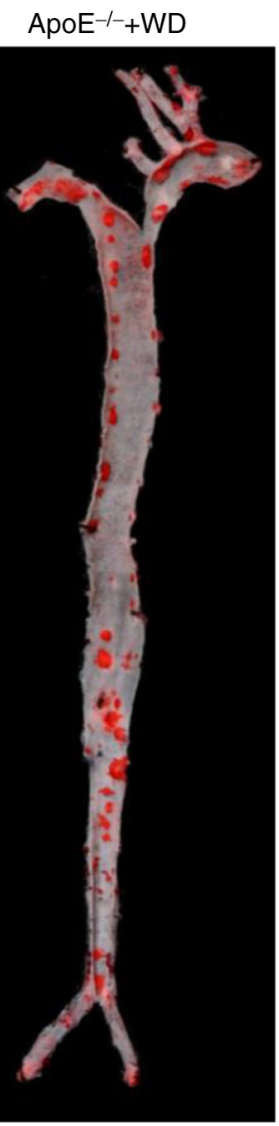

B
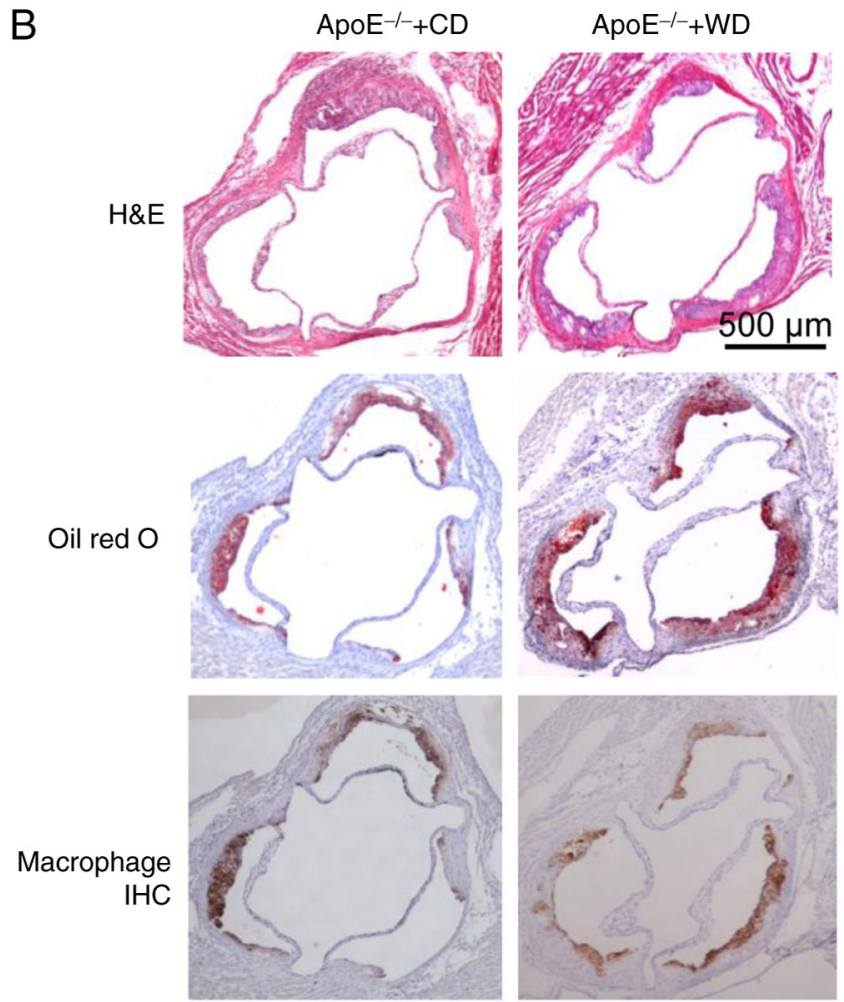

Figure 3. Atherosclerotic lesion in mice. (A) En face oil red O staining of aorta from 8-week-old ApoE ${ }^{-/-}+\mathrm{CD}_{\text {or } \mathrm{ApoE}}{ }^{-/}+\mathrm{WD}$ for 12 weeks. (B) Cross-section of aortic roots from 8-week-old ApoE ${ }^{-/}+\mathrm{CD}_{\text {or }} \mathrm{ApoE}^{-/}+\mathrm{WD}$ for 12 weeks, stained with H\&E, oil red O (atherosclerosis), or MOMA2 (macrophage) antibody. These data are unpublished. CD, chow diet; WD, western diet; H\&E, hematoxylin-eosin.

tree of mice was completely isolated, and the vessel wall was unraveled along the lumen. After fixation, oil red $\mathrm{O}$ staining, and imaging, the area of atherosclerotic plaque in the entire aortic tree was estimated using an image processing software. Representative images of aortic tree lesions and aortic root lesions are shown in Fig. 3A and B.

\section{Practical methods of using rabbits in atherosclerosis re- search}

Most of the rabbits used in atherosclerosis research were outbred strains. Therefore, it is necessary to screen rabbits before the formal experiment to exclude rabbits that are insensitive and extremely sensitive to HFHC diets. Male rabbits are often selected for atherosclerosis research. The cholesterol content in HFHC diet-fed mice is generally $<1.0 \%$ to decrease the liver damage caused by cholesterol. In the following section, the method that was used to develop a rabbit model of atherosclerosis in the laboratory will be elucidated $(70,72,89,90)$.

In the laboratory, 4-month-old male rabbits were fed a diet containing $0.3 \%$ cholesterol, for 16 weeks (for aorta lesion) or 28 weeks (for coronary lesion). During HFHC feeding, blood lipid levels were measured every 2 weeks. Similar to that in mice, the distribution of lesions in rabbit aorta is an important indicator for assessing whether diets have an impact on atherosclerosis. The practical operation process for rabbit aortic tree separation and atherosclerotic lesion analysis is shown in Fig. 4. Briefly, after the rabbits were euthanized and the organs (except the heart and kidney) were dissected, the entire aorta was separated from the heart to the iliac bifurcation, and the adipose tissues covering the aorta were removed. Thereafter, the intimal surface of the artery was exposed by making a longitudinal cut. After fixation, Sudan IV staining, and imaging, atherosclerotic lesions were analyzed using an imaging software. Representative images of atherosclerotic lesions in the aorta of rabbits on a normal or HFHC diet are shown in Fig. 5A. For histological examination, the entire aortic arch was serially sectioned at $1-2 \mathrm{~mm}$ intervals. Representative samples from these sections were processed routinely and embedded longitudinally in paraffin. The sections $(4 \mu \mathrm{m})$ were then stained with hematoxylin-eosin (H\&E) and elastic van Gieson (Fig. 5B) or immunohistochemistry.

\section{Noninvasive imaging of animal model in atherosclerosis}

More recently, researchers have paid more attention to the study of plaque composition and vulnerability, rather than the severity of stenosis of atherosclerotic plaque (91). Benefit from the development of imaging technology, multiple non-invasive systems have been developed to detect morphology and component of atherosclerosis lesions, including ultrasound, computed tomography (CT), magnetic resonance imaging (MRI), positron emission computed tomography (PET). Ultrasound is a relatively 


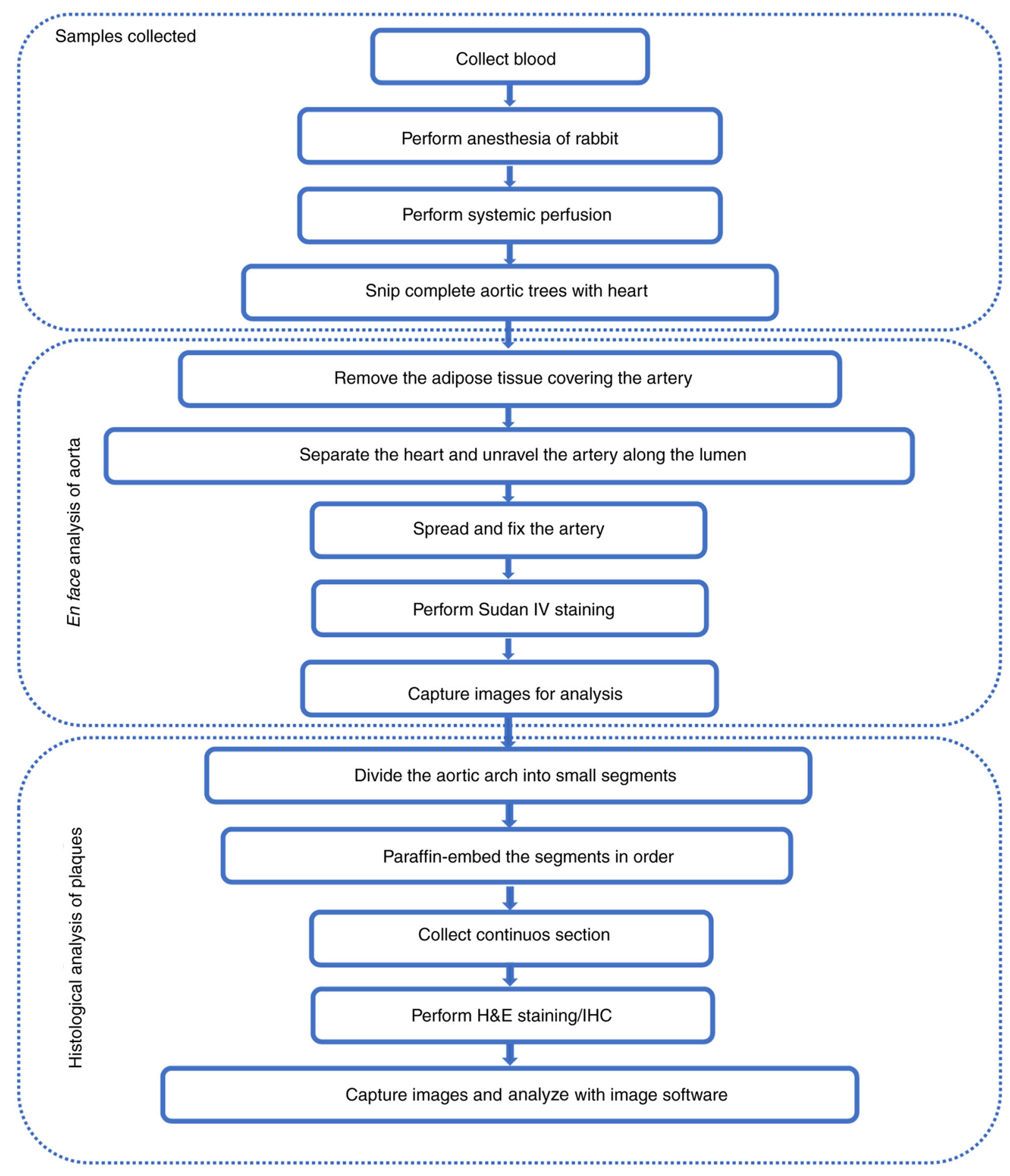

Figure 4. Procedure of atherosclerotic lesion quantification in rabbits. H\&E, hematoxylin-eosin; IHC, immunohistochemistry.

inexpensive, radiation-free test that can be used to determine the location of lesions and the thickness of blood vessel walls. Ultrasound has been reported to detect atherosclerosis in mice and rabbits (92-94). CT can provide quantitative assessment of the extent of vascular calcification (95). MRI and PET were the modalities used to perform molecular imaging. MRI can provide high-resolution vascular morphology images that can distinguish the lipid-rich necrotic core, fibrous cap, calcification and intraplaque hemorrhage $(96,97)$. Targeted specific MRI contrast agents can be used to detect components in plaques, but they are insensitive. PET is a quantitative nuclear imaging technique that allows the visualization of radioisotopes and is mostly applied to investigate tissue metabolic and physiological state at the molecular level with high sensitivity, but PET cannot be used to detect plaque morphology (98). Imaging of PET must be combined with CT imaging (PET/CT) or magnetic resonance imaging (PET/MRI) to localize the pathophysiological processes to an anatomical location. 18F-fluorodeoxyglucose (FDG) is the most common radioligand used in imaging studies of atherosclerosis (98). Hybrid PET/CT or PET/MRI has been reported to use in mice and rabbit atherosclerosis models to identify macrophages or chemokines in plaques (99-102). 
A

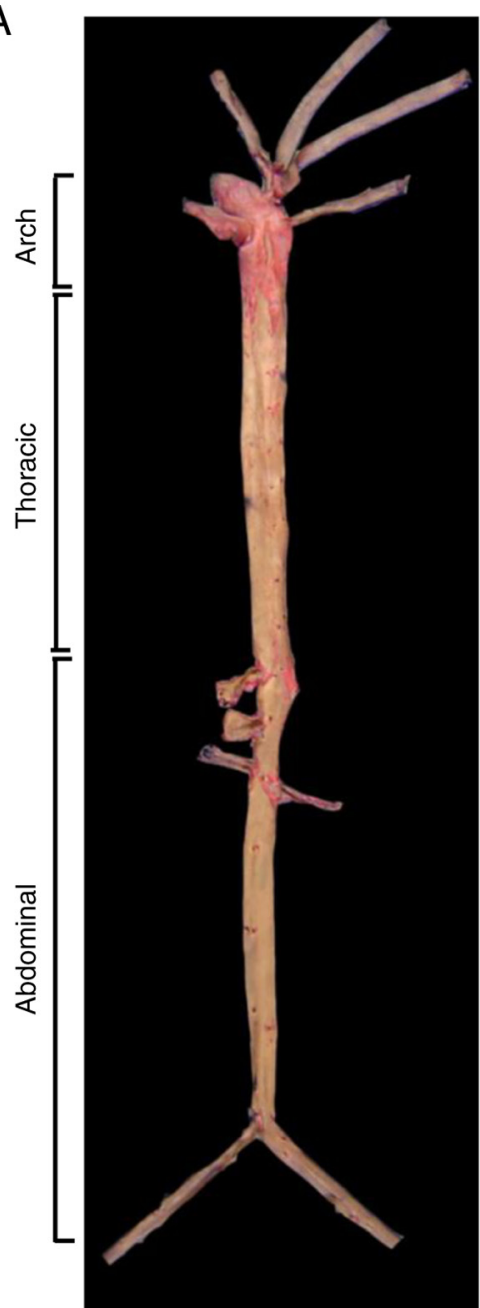

B $H \& E$

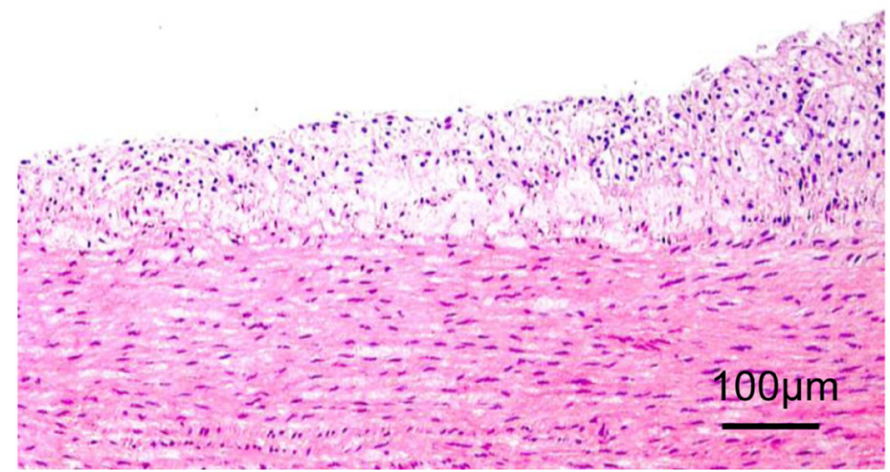

EVG

Figure 5. Atherosclerotic lesion in rabbit. (A) En face Sudan IV staining of aorta from rabbit fed with high cholesterol diet (0.3\% cholesterol) for 16 weeks (B) Paraffin sections of the aortic arch from rabbits fed with high cholesterol diet ( $0.3 \%$ cholesterol) for 16 weeks, stained with H\&E and EVG. These data are unpublished. H\&E, hematoxylin-eosin; EVG, elastic van Gieson.

Non-invasive imaging has a great application prospect in atherosclerosis. Previous research revealed that vulnerable plaques were characterized by increased content of macrophages and angiogenesis. In the future, molecular imaging techniques have a high potential to shed light on specific molecular/cellular processes and biomarkers of vulnerable plaques. Preclinical studies of medication and contrast agent need validation in animal models, thus, it is very valuable to develop applicable non-invasive imaging systems for small animals.

\section{In vitro study of atherosclerosis}

Cell cultures are essential for studying the specific molecular mechanisms of diseases. The cell types that are usually employed in atherosclerosis research include endothelial cells, macrophages and smooth muscle cells. Atherosclerosis begins with endothelial dysfunction, which causes endothelial cells to release adhesion factors and chemokines (2) that recruit macrophages to accumulate in the intima. Macrophages induce the release of growth factors and chemokines to promote smooth muscle cell proliferation and migration $(5,7)$. Simultaneously, macrophages swallowing lipids lead to foam formation (103).
In the following section, the methods of primary cell culture and some applications are mentioned.

Endothelial cell. The endothelium acts as the first barrier to vascular protection and has multiple important physiological functions (104). Endothelial injury and dysfunction are considered initial events in the development of atherosclerotic lesions (2).

Human umbilical vein endothelial cells (HUVECs) are the most widely used model in endothelial cell-based studies. This wide application is due to the easy access to fetal umbilical cord, convenient cell extraction operation, as the acquisition of abundant endothelial cells is the guarantee for the establishment of cell models in vitro. In addition, HUVECs have representative physiological and pathological characteristics of adult endothelial cells. This model has been employed in the study of endothelial cell function and in elucidating the role of endothelium in the blood vessel wall response towards stretching, shear forces and reactive oxygen species generation (105-107). Since HUVECs are derived from the fetus, differences with adult endothelial cells should be considered. It was reported that HUVECs were unable to express ABO blood group antigens, 
Table II. Cell types commonly used in atherosclerosis research.

Commonly

used cell lines
Application

\begin{tabular}{llll} 
Cell type & \multicolumn{1}{c}{ Commonly used primary cells } & used cell lines & \multicolumn{1}{c}{ Application } \\
\hline Endothelial cell & $\begin{array}{l}\text { Human umbilical vein endothelial cells; } \\
\text { human microvascular endothelial cells }\end{array}$ & & $\begin{array}{l}\text { Endothelial cell dysfunction; } \\
\text { inflammatory response }\end{array}$ \\
Macrophage & $\begin{array}{l}\text { Peritoneal macrophages } \\
\text { Bone marrow-derived macrophages }\end{array}$ & $\begin{array}{l}\text { THP1, J774a.1 } \\
\text { and U937 } \\
\text { Shagocytosis; proliferation; migration; } \\
\text { adhesion; polarization }\end{array}$ \\
& $\begin{array}{l}\text { Vascular smooth muscle cells from rat; } \\
\text { vascular smooth muscle cells from mice }\end{array}$ & $\begin{array}{l}\text { A7r5 and } \\
\text { MOVAS-1 }\end{array}$ & $\begin{array}{l}\text { Calcification; phenotype transformation; } \\
\text { proliferation; migration }\end{array}$ \\
\hline
\end{tabular}

which may significantly affect their surface function (108). It has also been reported that the sex of the fetus may affect the physiological function of endothelial cells $(105,109)$.

Several protocols for HUVEC isolation have been established (107,110-112). In short, the first step involved rinsing the umbilical cord ( 10-30 $\mathrm{cm})$ with phosphate-buffered saline (PBS) in a sterile environment. Thereafter, one end of the umbilical cord was closed with hemostatic forceps, and 0.1 or $0.2 \%$ collagenase solution was poured from the other end. After the completion of perfusion, both ends of the umbilical cord were closed and incubated at $37^{\circ} \mathrm{C}$ for $10-20 \mathrm{~min}$. After the completion of digestion, culture medium containing fetal bovine serum (FBS) was injected into the umbilical cord to terminate the digestion process. The endothelium was further eluted with $30 \mathrm{ml}$ PBS, and the collected cells were centrifuged and counted. Finally, the cells were cultured in M199 complete medium supplemented with FBS and penicillin-streptomycin and incubated at $37^{\circ} \mathrm{C}$ in a $5 \% \mathrm{CO}_{2}$ atmosphere. The most commonly used method for HUVEC identification is the immunofluorescence staining of von Willebrand factor, VIII factor, and CD31 (113).

Macrophage. Macrophages play crucial roles at all stages of atherosclerosis, from initiation of lesion formation and expansion to necrosis leading to rupture, the clinical manifestations of atherosclerosis, and resolution and regression of atherosclerotic lesions (114). Macrophages that phagocytose oxidized LDL are the main source of foam cells, which are the main components of atherosclerotic plaques (115). During the activation of macrophages, more growth factors and chemokines are released, leading to platelet aggregation at the site of injury, while promoting smooth muscle cell proliferation and migration (116).

Mouse peritoneal macrophages, bone marrow-derived macrophages, mouse mononuclear macrophage cell lines (RAW264.7), and human monocyte cell lines (THP-1) are commonly used in macrophage-based studies.

The procedure for isolating murine macrophages has been reported $(86,117)$. For PM isolation, mice were injected with $1.0 \mathrm{ml} \mathrm{3 \%}$ sodium thioglycolate for 3 days before isolating macrophages. Peritoneal lavage was performed with 5-8 $\mathrm{ml}$ sterile PBS or RPMI-1640 medium. After centrifugation and washing with PBS, the cells were resuspended in culture medium. Finally, the cells were added to a culture plate in order to allow the macrophages to adhere to the wall, and the medium was changed after $2 \mathrm{~h}$ to obtain macrophages with high purity. For BMDM isolation from mice, bone marrow cells were harvested and cultured in medium supplemented with macrophage colony-stimulating factor. After 7 days of culturing, contaminating non-adherent cells were eliminated and adherent cells were harvested for further assays. Macrophages were then identified via immunostaining using F4/80 antibodies (118).

Smooth muscle cell. Smooth muscle cells constitute the media layer of the arteries. In atherosclerotic lesions, smooth muscle cells proliferate and migrate to the intima upon inflammation, and collagen fibers are secreted to form plaque fibrous caps (7). Therefore, the number and function of smooth muscle cells often affect the stability of atherosclerotic plaques. In an atherogenic environment, smooth muscle cells present in the lesion phagocytose the modified lipoprotein to form smooth muscle-derived foam cells, which then secrete inflammatory factors, thereby aggravating the inflammation of the lesion (119).

Rat and mouse primary smooth muscle cells are commonly used in atherosclerosis research, including cell proliferation, migration, calcification and phenotypic transformation studies.

The commonly used method for the isolation of rat smooth muscle cells is tissue transplantation (120). The procedure of tissue transplantation included the following steps: Isolating the aortic artery; separating the media from it; and cutting the aortic artery into small pieces, followed by incubation in complete medium until the cells reach confluence. The rats were euthanized by anesthesia, and their thoracic aorta was isolated. The aorta was cut in Dulbecco's modified Eagle's medium (high glucose) supplemented with $20 \%$ FBS, and the inner wall of the blood vessel was slightly scraped to destroy the endothelium. After carefully removing the outer membrane of the blood vessel, the medium layer was cut into small pieces of 2-4 $\mathrm{mm}^{2}$ and spread evenly on the bottom of a cell culture flask. After $4 \mathrm{~h}$, the tissue block was gently attached, and the flask was slowly inverted to cover the tissue. Thereafter, the culture medium was changed every 3 days, and after $\sim 1$ week, the culture flask was examined under a microscope. The smooth muscle cells were observed to grow out of the tissue block and cover the surrounding bottle wall. The cells were passaged once they reached a confluence of $\sim 70-80 \%$. Smooth muscle cells were then identified via immunostaining with an anti- $\alpha$-actin antibody.

The primary cells, cell lines, and the corresponding experiments commonly used for atherosclerosis research are shown in Table II. 


\section{Conclusion}

The generation of $\mathrm{ApoE}^{-/-}$and $\mathrm{LDLR}^{-/-}$mice was a milestone in atherosclerosis research, because of their ease of gene manipulation, which expanded the scope of research into atherosclerosis and provided elaborate insights into molecular mechanisms, especially in lipid metabolism and inflammatory pathways. HFHC diet-induced rabbit models are widely used, and WHHL rabbits showing symptoms of plaque rupture and myocardial infarction are excellent animal models for mimicking human atherosclerosis. Other animals used for atherosclerosis research include pigs, non-human primates, rats, dogs, and quails; however, they are not widely used owing to high costs, ethical issues, slow modeling, and genetic background. As different animal models have their own advantages and limitations, suitable animals need to be chosen according to the purpose of the study. Mice are most commonly used to elucidate molecular mechanisms, because they have a clear genetic background and are easy to genetically modify. For drug development studies, mice and rabbits are chosen because of their small size and requirement of decreasing drug dosage. In general, dogs are commonly used to simulate clinical surgeries because of the ease to operate given their large size. In brief, animal models of each species can only mimic some characteristics of human atherosclerosis. Therefore, a scientific problem can be verified through performing research at different levels (in vivo vs. in vitro) and in animal models of different species. With the development of gene editing technology, especially with the emergence of the clustered regularly interspaced short palindromic repeats (CRISPR)-associated protein 9 system (CRISPR/Cas9) and somatic cell nuclear transfer, more laboratory animal strains may be used as study models of atherosclerosis in the future. For instance, $\mathrm{ApoE}^{-/-}$pigs and $\mathrm{ApoE}^{-/-}$dogs were produced using the CRISPR/Cas9 system in 2018 (121,122). Further research on atherosclerosis still relies on animal models; however, bridging the gap between basic research and clinical applications is an important issue for future researchers to consider, which can be achieved by developing a suitable animal model.

\section{Acknowledgements}

Not applicable.

\section{Funding}

This work was supported by the Science Plan Project of Shaanxi Province (grant nos. 2020PT-001 and 2019JQ-599).

\section{Availability of data and materials}

Not applicable.

\section{Authors' contributions}

YZ designed the review, prepared the tables and figures, and wrote the manuscript. MF and $\mathrm{SH}$ searched the literature and wrote the manuscript. LB and SZ provided helpful comments and acquired data. EL conceived this review and revised the manuscript. All authors read and approved the final manuscript. Data authentication is not applicable.

\section{Ethics approval and consent to participate}

Not applicable.

\section{Patient consent for publication}

Not applicable.

\section{Competing interests}

The authors declare that they have no competing interests.

\section{References}

1. Libby P, Ridker PM and Hansson GK: Progress and challenges in translating the biology of atherosclerosis. Nature 473: 317-325, 2011.

2. Gimbrone MA Jr and Garcia-Cardena G: Endothelial cell dysfunction and the pathobiology of atherosclerosis. Circ Res 118: 620-636, 2016.

3. Sena CM, Leandro A, Azul L, Seica R and Perry G: Vascular oxidative stress: Impact and therapeutic approaches. Front Physiol 9: 1668, 2018.

4. Chistiakov DA, Orekhov AN and Bobryshev YV: Effects of shear stress on endothelial cells: Go with the flow. Acta Physiol (Oxf) 219: 382-408, 2017.

5. Moore KJ, Sheedy FJ and Fisher EA: Macrophages in atherosclerosis: A dynamic balance. Nat Rev Immunol 13: 709-721, 2013.

6. Chistiakov DA, Melnichenko AA, Myasoedova VA, Grechko AV and Orekhov AN: Mechanisms of foam cell formation in atherosclerosis. J Mol Med (Berl) 95: 1153-1165, 2017.

7. Bennett MR, Sinha S and Owens GK: Vascular smooth muscle cells in atherosclerosis. Circ Res 118: 692-702, 2016.

8. Davignon J and Ganz P: Role of endothelial dysfunction in atherosclerosis. Circulation 109 (23 Suppl 1): III27-III32, 2004.

9. Incalza MA, D'Oria R, Natalicchio A, Perrini S, Laviola L and Giorgino F: Oxidative stress and reactive oxygen species in endothelial dysfunction associated with cardiovascular and metabolic diseases. Vascul Pharmacol 100: 1-19, 2018.

10. Hajjar DP and Gotto AM Jr: Biological relevance of inflammation and oxidative stress in the pathogenesis of arterial diseases. Am J Pathol 182: 1474-1481, 2013.

11. Rhoads JP and Major AS: How oxidized low-density lipoprotein activates inflammatory responses. Crit Rev Immunol 38: 333-342, 2018.

12. Zhang T, Chen J, Tang X, Luo Q, Xu D and Yu B: Interaction between adipocytes and high-density lipoprotein: New insights into the mechanism of obesity-induced dyslipidemia and atherosclerosis. Lipids Health Dis 18: 223, 2019.

13. Ference BA, Ginsberg HN, Graham I, Ray KK, Packard CJ, Bruckert E, Hegele RA, Krauss RM, Raal FJ, Schunkert H, et al: Low-density lipoproteins cause atherosclerotic cardiovascular disease. 1. Evidence from genetic, epidemiologic, and clinical studies. A consensus statement from the European atherosclerosis society consensus panel. Eur Heart J 38: 2459-2472, 2017.

14. Messner B and Bernhard D: Smoking and cardiovascular disease: Mechanisms of endothelial dysfunction and early atherogenesis. Arterioscler Thromb Vasc Biol 34: 509-515, 2014.

15. Altman R: Risk factors in coronary atherosclerosis athero-inflammation: The meeting point. Thromb J 1: 4, 2003.

16. Hollander W: Role of hypertension in atherosclerosis and cardiovascular disease. Am J Cardiol 38: 786-800, 1976.

17. Katakami N: Mechanism of development of atherosclerosis and cardiovascular disease in diabetes mellitus. J Atheroscler Thromb 25: 27-39, 2018.

18. Virani SS, Alonso A, Benjamin EJ, Bittencourt MS, Callaway CW, Carson AP, Chamberlain AM, Chang AR, Cheng S, Delling FN, et al: Heart disease and stroke statistics-2020 update: A report from the american heart association. Circulation 141: e139-e596, 2020. 
19. Lenfant $C$ and Savage PJ: The early natural history of atherosclerosis and hypertension in the young: National institutes of health perspectives. Am J Med Sci 310 (Suppl 1): S3-S7, 1995.

20. McNamara JJ, Molot MA, Stremple JF and Cutting RT: Coronary artery disease in combat casualties in Vietnam. JAMA 216 1185-1187, 1971.

21. Strong JP, Mcgill HC Jr, Tejada C and Holman RL: The natura history of atherosclerosis; comparison of the early aortic lesions in New Orleans, Guatemala, and Costa Rica. Am J Pathol 34 731-744, 1958

22. Enos WF, Holmes RH and Beyer J: Coronary disease among United States soldiers killed in action in Korea; preliminary report. J Am Med Assoc 152: 1090-1093, 1953.

23. Konstantinov IE and Jankovic GM: Alexander I. Ignatowski: A pioneer in the study of atherosclerosis. Tex Heart Inst J 40: 246-249, 2013.

24. Daugherty A, Tall AR, Daemen M, Falk E, Fisher EA, García-Cardeña G, Lusis AJ, Owens AP III, Rosenfeld ME, Virmani R, et al: Recommendation on design, execution, and reporting of animal atherosclerosis studies: A scientific statement from the american heart association. Arterioscler Thromb Vasc Biol 37: e131-e157, 2017.

25. Wu C, Daugherty A and Lu HS: Updates on approaches for studying atherosclerosis. Arterioscler Thromb Vasc Biol 39: e108-e117, 2019.

26. Fan J, Chen Y, Yan H, Niimi M, Wang Y and Liang J: Principles and applications of rabbit models for atherosclerosis research. J Atheroscler Thromb 25: 213-220, 2018.

27. Vesselinovitch D, Wissler RW and Doull J: Experimental production of atherosclerosis in mice. 1. Effect of various synthetic diets and radiation on survival time, food consumption and body weight in mice. J Atheroscler Res 8: 483-495, 1968.

28. Vesselinovitch D and Wissler RW: Experimental production of atherosclerosis in mice. 2. Effects of atherogenic and high-fat diets on vascular changes in chronically and acutely irradiated mice. J Atheroscler Res 8: 497-523, 1968.

29. Thompson JS: Atheromata in an inbred strain of mice. J Atheroscler Res 10: 113-122, 1969.

30. Paigen B, Morrow A, Brandon C, Mitchell D and Holmes P: Variation in susceptibility to atherosclerosis among inbred strains of mice. Atherosclerosis 57: 65-73, 1985

31. Ishibashi S, Brown MS, Goldstein JL, Gerard RD, Hammer RE and Herz J: Hypercholesterolemia in low density lipoprotein receptor knockout mice and its reversal by adenovirus-mediated gene delivery. J Clin Invest 92: 883-893, 1993

32. Plump AS, Smith JD, Hayek T, Aalto-Setälä K, Walsh A, Verstuyft JG, Rubin EM and Breslow JL: Severe hypercholesterolemia and atherosclerosis in apolipoprotein E-deficient mice created by homologous recombination in ES cells. Cell 71: 343-353, 1992.

33. Piedrahita JA, Zhang SH, Hagaman JR, Oliver PM and Maeda N: Generation of mice carrying a mutant apolipoprotein E gene inactivated by gene targeting in embryonic stem cells. Proc Natl Acad Sci USA 89: 4471-4475, 1992.

34. Olszanecki R and Korbut R: The effect of montelukast on atherogenesis in apoE/LDLR-double knockout mice. J Physiol Pharmacol 59: 633-639, 2008.

35. Olszanecki R, Jawien J, Gajda M, Mateuszuk L, Gebska A, Korabiowska M, Chłopicki S and Korbut R: Effect of curcumin on atherosclerosis in apoE-LDLR-double knockout mice. J Physiol Pharmacol 4: 627-635, 2005.

36. Schilperoort M, van den Berg R, Bosmans LA, van Os BW, Dollé ME, Smits NA, Guichelaar T, van Baarle D, Koemans L, Berbée JF, et al: Disruption of circadian rhythm by alternating light-dark cycles aggravates atherosclerosis development in APOE* 3-leiden. CETP mice. J Pineal Res 68: e12614, 2020.

37. Berbée JF, Wong MC, Wang Y, van der Hoorn JW, Khedoe PP, van Klinken JB, Mol IM, Hiemstra PS, Tsikas D, Romijn JA, et al: Resveratrol protects against atherosclerosis, but does not add to the antiatherogenic effect of atorvastatin, in APOE* 3-leiden. CETP mice. J Nutr Biochem 24: 1423-1430, 2013.

38. de Haan W, van der Hoogt CC, Westerterp M, Hoekstra M, Dallinga-Thie GM, Princen HM, Romijn JA, Jukema JW, Havekes LM and Rensen PC: Atorvastatin increases HDL cholesterol by reducing CETP expression in cholesterol-fed APOE* 3-leiden. CETP mice. Atherosclerosis 197: 57-63, 2008.

39. Stein EA and Raal F: Reduction of low-density lipoprotein cholesterol by monoclonal antibody inhibition of PCSK9. Annu Rev Med 65: 417-431, 2014
40. Getz GS and Reardon CA: Apoprotein E as a lipid transport and signaling protein in the blood, liver, and artery wall. J Lipid Res (50 Suppl): S156-S161, 2009.

41. Sehayek E, Shefer S, Nguyen LB, Ono JG, Merkel M and Breslow JL: Apolipoprotein E regulates dietary cholesterol absorption and biliary cholesterol excretion: studies in C57BL/6 apolipoprotein E knockout mice. Proc Natl Acad Sci USA 97: 3433-3437, 2000

42. Plump AS and Breslow JL: Apolipoprotein E and the apolipoprotein E-deficient mouse. Annu Rev Nutr 15: 495-518, 1995.

43. Nakashima Y, Plump AS, Raines EW, Breslow JL and Ross R: ApoE-deficient mice develop lesions of all phases of atherosclerosis throughout the arterial tree. Arterioscler Thromb 14: 133-140, 1994

44. Rattazzi M, Bennett BJ, Bea F, Kirk EA, Ricks JL, Speer M, Schwartz SM, Giachelli CM and Rosenfeld ME: Calcification of advanced atherosclerotic lesions in the innominate arteries of ApoE-deficient mice: Potential role of chondrocyte-like cells. Arterioscler Thromb Vasc Biol 25: 1420-1425, 2005.

45. Meir KS and Leitersdorf E: Atherosclerosis in the apolipoprotein-E-deficient mouse: a decade of progress. Arterioscler Thromb Vasc Biol 24: 1006-1014, 2004.

46. Oppi S, Luscher TF and Stein S: Mouse models for atherosclerosis research-which is my line? Front Cardiovasc Med 6: 46, 2019.

47. von Scheidt M, Zhao Y, Kurt Z, Pan C, Zeng L, Yang X, Schunkert $\mathrm{H}$ and Lusis AJ: Applications and limitations of mouse models for understanding human atherosclerosis. Cell Metab 25: 248-261, 2017.

48. Moore KJ, Kunjathoor VV, Koehn SL, Manning JJ, Tseng AA, Silver JM, McKee M and Freeman MW: Loss of receptormediated lipid uptake via scavenger receptor A or CD36 pathways does not ameliorate atherosclerosis in hyperlipidemic mice. J Clin Invest 115: 2192-2201, 2005.

49. Go GW and Mani A: Low-density lipoprotein receptor (LDLR) family orchestrates cholesterol homeostasis. Yale J Biol Med 85: $19-28,2012$.

50. Ishibashi S, Goldstein JL, Brown MS, Herz J and Burns DK: Massive xanthomatosis and atherosclerosis in cholesterol-fed low density lipoprotein receptor-negative mice. J Clin Invest 93: 1885-1893, 1994

51. Moore RE, Kawashiri MA, Kitajima K, Secreto A, Millar JS, Pratico D and Rader DJ: Apolipoprotein A-I deficiency results in markedly increased atherosclerosis in mice lacking the LDL receptor. Arterioscler Thromb Vasc Biol 23: 1914-1920, 2003.

52. Getz GS and Reardon CA: Diet and murine atherosclerosis. Arterioscler Thromb Vasc Biol 26: 242-249, 2006.

53. Boisvert WA, Spangenberg J and Curtiss LK: Role of leukocyte-specific LDL receptors on plasma lipoprotein cholesterol and atherosclerosis in mice. Arterioscler Thromb Vasc Biol 17: 340-347, 1997.

54. Herijgers N, Van Eck M, Groot PH, Hoogerbrugge PM and Van Berkel TJ: Effect of bone marrow transplantation on lipoprotein metabolism and atherosclerosis in LDL receptor-knockout mice. Arterioscler Thromb Vasc Biol 17: 1995-2003, 1997.

55. Linton MF, Atkinson JB and Fazio S: Prevention of atherosclerosis in apolipoprotein E-deficient mice by bone marrow transplantation. Science 267: 1034-1037, 1995.

56. Boisvert WA, Spangenberg J and Curtiss LK: Treatment of severe hypercholesterolemia in apolipoprotein E-deficient mice by bone marrow transplantation. J Clin Invest 96: 1118-1124, 1995.

57. Roche-Molina M, Sanz-Rosa D, Cruz FM, García-Prieto J, López S, Abia R, Muriana FJ, Fuster V, Ibáñez B and Bernal JA: Induction of sustained hypercholesterolemia by single adeno-associated virus-mediated gene transfer of mutant hPCSK9. Arterioscler Thromb Vasc Biol 35: 50-59, 2015.

58. Bjorklund MM,Hollensen AK, Hagensen MK, Dagnaes-Hansen F, Christoffersen C, Mikkelsen JG and Bentzon JF: Induction of atherosclerosis in mice and hamsters without germline genetic engineering. Circ Res 114: 1684-1689, 2014.

59. Goettsch C, Hutcheson JD, Hagita S, Rogers MA, Creager MD, Pham T, Choi J, Mlynarchik AK, Pieper B, Kjolby M, et al: A single injection of gain-of-function mutant PCSK9 adenoassociated virus vector induces cardiovascular calcification in mice with no genetic modification. Atherosclerosis 251: 109-118, 2016.

60. Veseli BE, Perrotta P, De Meyer GRA, Roth L, der Donckt CV, Martinet W and De Meyer GR: Animal models of atherosclerosis. Eur J Pharmacol 816: 3-13, 2017. 
61. Zhang S, Picard MH, Vasile E, Zhu Y, Raffai RL, Weisgraber KH and Krieger M: Diet-induced occlusive coronary atherosclerosis, myocardial infarction, cardiac dysfunction, and premature death in scavenger receptor class B type I-deficient, hypomorphic apolipoprotein ER61 mice. Circulation 111: 3457-3464, 2005.

62. Westerterp M, van der Hoogt CC, de Haan W, Offerman EH, Dallinga-Thie GM, Jukema JW, Havekes LM and Rensen PC: Cholesteryl ester transfer protein decreases high-density lipoprotein and severely aggravates atherosclerosis in APOE*3-leiden mice. Arterioscler Thromb Vasc Biol 26 2552-2559, 2006.

63. van den Maagdenberg AM, Hofker MH, Krimpenfort PJ, de Bruijn I, van Vlijmen B, van der Boom H, Havekes LM and Frants RR: Transgenic mice carrying the apolipoprotein E3-Leiden gene exhibit hyperlipoproteinemia. J Biol Chem 268: 10540-10545, 1993.

64. Berbee JF, Boon MR, Khedoe PP, Bartelt A, Schlein C, Worthmann A, Kooijman S, Hoeke G, Mol IM, John C, et al: Brown fat activation reduces hypercholesterolaemia and protects from atherosclerosis development. Nat Commun 6: 6356, 2015

65. Van der Donckt C, Van Herck JL, Schrijvers DM, Vanhoutte G, Verhoye M, Blockx I, Van Der Linden A, Bauters D, Lijnen HR, Sluimer JC, et al: Elastin fragmentation in atherosclerotic mice leads to intraplaque neovascularization, plaque rupture, myocardial infarction, stroke, and sudden death. Eur Heart J 36: $1049-1058,2015$.

66. Roth L, Rombouts M, Schrijvers DM, Lemmens K, De Keulenaer GW, Martinet W and De Meyer GR: Chronic intermittent mental stress promotes atherosclerotic plaque vulnerability, myocardial infarction and sudden death in mice. Atherosclerosis 242: 288-294, 2015.

67. Steinberg D: In celebration of the 100th anniversary of the lipid hypothesis of atherosclerosis. J Lipid Res 54: 2946-2949, 2013

68. Fan J and Watanabe T: Cholesterol-fed and transgenic rabbit models for the study of atherosclerosis. J Atheroscler Thromb 7: 26-32, 2000

69. Fan J, Kitajima S, Watanabe T, Xu J, Zhang J, Liu E and Chen YE: Rabbit models for the study of human atherosclerosis: From pathophysiological mechanisms to translational medicine. Pharmacol Ther 146: 104-119, 2015.

70. Niimi M, Yang D, Kitajima S, Ning B, Wang C,Li S, Liu E, Zhang J, Chen YE and Fan J: ApoE knockout rabbits: A novel model for the study of human hyperlipidemia. Atherosclerosis 245: 187-193, 2016.

71. Matsuhisa F, Kitajima S, Nishijima K, Akiyoshi T, Morimoto M and Fan J: Transgenic rabbit models: Now and the future. Applied Sciences 10: 7416, 2020.

72. Yu QQ, Cheng DX, Xu LR, Li YK, Zheng XY, Liu Y, Li YF, Liu HL, Bai L, Wang R, et al: Urotensin II and urantide exert opposite effects on the cellular components of atherosclerotic plaque in hypercholesterolemic rabbits. Acta Pharmacol Sin 41: 546-553, 2020

73. Chen $Y$, Waqar AB, Nishijima K, Ning B, Kitajima S, Matsuhisa F, Chen L, Liu E, Koike T, Yu Y, et al: Macrophage-derived MMP-9 enhances the progression of atherosclerotic lesions and vascular calcification in transgenic rabbits. J Cell Mol Med 24: 4261-4274, 2020.

74. Gao S, Wang X, Cheng D, Li J, Li L, Ran L, Zhao S, Fan J and Liu E: Overexpression of cholesteryl ester transfer protein increases macrophage-derived foam cell accumulation in atherosclerotic lesions of transgenic rabbits. Mediators Inflamm 2017: 3824276, 2017.

75. Ding Y, Wang Y, Zhu H, Fan J, Yu L, Liu G and Liu E: Hypertriglyceridemia and delayed clearance of fat load in transgenic rabbits expressing human apolipoprotein CIII Transgenic Res 20: 867-875, 2011.

76. Koike T, Kitajima S, Yu Y, Li Y, Nishijima K, Liu E, Sun H, Waqar AB, Shibata N, Inoue T, et al: Expression of human apoAII in transgenic rabbits leads to dyslipidemia: A new model for combined hyperlipidemia. Arterioscler Thromb Vasc Biol 29 2047-2053, 2009.

77. Wang C, Nishijima K, Kitajima S, Niimi M, Yan H, Chen Y, Ning B, Matsuhisa F, Liu E, Zhang J, et al: Increased hepatic expression of endothelial lipase inhibits cholesterol diet-induced hypercholesterolemia and atherosclerosis in transgenic rabbits. Arterioscler Thromb Vasc Biol 37: 1282-1289, 2017.

78. Watanabe Y: Serial inbreeding of rabbits with hereditary hyperlipidemia (WHHL-rabbit). Atherosclerosis 36: 261-268, 1980.
79. Shiomi M and Ito T: The Watanabe heritable hyperlipidemic (WHHL) rabbit, its characteristics and history of development: A tribute to the late Dr. Yoshio Watanabe. Atherosclerosis 207: 1-7, 2009.

80. Masashi S and Takashi I: The Watanabe heritable hyperlipidemic (WHHL) rabbit, its characteristics and history of development: A tribute to the late Dr. Yoshio Watanabe. Atherosclerosis 207: 1-7, 2009.

81. Ning B, Wang X, Yu Y, Waqar AB, Yu Q, Koike T, Shiomi M, Liu E, Wang Y and Fan J: High-fructose and high-fat diet-induced insulin resistance enhances atherosclerosis in Watanabe heritable hyperlipidemic rabbits. Nutr Metab (Lond) 12: 30, 2015.

82. Lichtman AH, Clinton SK, Iiyama K, Connelly PW, Libby P and Cybulsky MI: Hyperlipidemia and atherosclerotic lesion development in LDL receptor-deficient mice fed defined semipurified diets with and without cholate. Arterioscler Thromb Vasc Biol 19: 1938-1944, 1999.

83. Reardon CA, Blachowicz L, Lukens J, Nissenbaum M and Getz GS: Genetic background selectively influences innominate artery atherosclerosis: Immune system deficiency as a probe. Arterioscler Thromb Vasc Biol 23: 1449-1454, 2003.

84. Lin Y, Bai L, Chen Y, Zhu N, Bai Y, Li Q, Zhao S, Fan J and Liu E: Practical assessment of the quantification of atherosclerotic lesions in apoE(-)/(-) mice. Mol Med Rep 12: 5298-5306, 2015.

85. Centa M, Ketelhuth DFJ, Malin S and Gisterå A: Quantification of atherosclerosis in mice. J Vis Exp 12: doi: 10.3791/59828, 2019.

86. Bai L, Li Z, Li Q, Guan H, Zhao S, Liu R, Wang R, Zhang J, Jia Y, Fan J, et al: Mediator 1 is atherosclerosis protective by regulating macrophage polarization. Arterioscler Thromb Vasc Biol 37: 1470-1481, 2017.

87. Wang R, Zhang Y, Xu L, Lin Y, Yang X, Bai L, Chen Y, Zhao S, Fan J, Cheng X and Liu E: Protein inhibitor of activated STAT3 suppresses oxidized LDL-induced cell responses during atherosclerosis in apolipoprotein E-deficient mice. Sci Rep 6: 36790 , 2016.

88. Guan H, Lin Y, Bai L, An Y, Shang J, Wang Z, Zhao S, Fan J and Liu E: Dietary cocoa powder improves hyperlipidemia and reduces atherosclerosis in apoE deficient mice through the inhibition of hepatic endoplasmic reticulum stress. Mediators Inflamm 2016: 1937572, 2016.

89. Li S, Wang YN, Niimi M, Ning B, Chen Y, Kang D, Wang Z, Yu Q, Waqar AB, Liu E, et al: Angiotensin II destabilizes coronary plaques in watanabe heritable hyperlipidemic rabbits. Arterioscler Thromb Vasc Biol 36: 810-816, 2016.

90. Yan H, Niimi M, Matsuhisa F, Zhou H, Kitajima S, Chen Y, Wang C, Yang X, Yao J, Yang D, et al: Apolipoprotein CIII deficiency protects against atherosclerosis in knockout rabbits. Arterioscler Thromb Vasc Biol 40: 2095-2107, 2020.

91. Dweck MR, Aikawa E, Newby DE, Tarkin JM, Rudd JH, Narula $\mathrm{J}$ and Fayad ZA: Noninvasive molecular imaging of disease activity in atherosclerosis. Circ Res 119: 330-340, 2016.

92. Chen Q, Yu J, Lukashova L, Latoche JD, Zhu J, Lavery L, Verdelis $\mathrm{K}$, Anderson $\mathrm{CJ}$ and $\mathrm{Kim} \mathrm{K}$ : validation of ultrasound super-resolution imaging of vasa vasorum in rabbit atherosclerotic plaques. IEEE Trans Ultrason Ferroelectr Freq Control 67: $1725-1729,2020$

93. Zhang X, Ha S, Wei W, Duan S, Shi Y and Yang Y: Noninvasive imaging of aortic atherosclerosis by ultrasound biomicroscopy in a mouse model. J Ultrasound Med 34: 111-116, 2015.

94. Punjabi M, Xu L, Ochoa-Espinosa A, Kosareva A, Wolff T, Murtaja A, Broisat A, Devoogdt N and Kaufmann BA: Ultrasound molecular imaging of atherosclerosis with nanobodies: Translatable microbubble targeting murine and human VCAM (Vascular Cell Adhesion Molecule) 1. Arterioscler Thromb Vasc Biol 39: 2520-2530, 2019.

95. Borland SJ, Behnsen J, Ashton N, Francis SE, Brennan K, Sherratt MJ, Withers PJ and Canfield AE: X-ray micro-computed tomography: An emerging technology to analyze vascular calcification in animal models. Int J Mol Sci 21: 4538, 2020.

96. Magnoni M, Ammirati E and Camici PG: Non-invasive molecular imaging of vulnerable atherosclerotic plaques. J Cardiol 65: 261-269, 2015.

97. Choudhury RP, Fuster V, Badimon JJ, Fisher EA and Fayad ZA: MRI and characterization of atherosclerotic plaque: Emerging applications and molecular imaging. Arterioscler Thromb Vasc Biol 22: 1065-1074, 2002 
98. Evans NR, Tarkin JM, Chowdhury MM, Warburton EA and Rudd JH: PET imaging of atherosclerotic disease: Advancing plaque assessment from anatomy to pathophysiology. Curr Atheroscler Rep 18: 30, 2016.

99. Calcagno C, Lairez O, Hawkins J, Kerr SW, Dugas MS, Simpson T, Epskamp J, Robson PM, Eldib M, Bander I, et al: Combined PET/DCE-MRI in a rabbit model of atherosclerosis: Integrated quantification of plaque inflammation, permeability, and burden during treatment with a leukotriene A4 hydrolase inhibitor. JACC Cardiovasc Imaging 11: 291-301, 2018.

100. Calcagno C, Perez-Medina C, Mulder WJM and Fayad ZA Whole-Body atherosclerosis imaging by positron emission tomography/magnetic resonance imaging: From mice to nonhuman primates. Arterioscler Thromb Vasc Biol 40 $1123-1134,2020$.

101. Luehmann HP, Detering L, Fors BP, Pressly ED, Woodard PK Randolph GJ, Gropler RJ, Hawker CJ and Liu Y: PET/CT imaging of chemokine receptors in inflammatory atherosclerosis using targeted nanoparticles. J Nucl Med 57: 1124-1129, 2016.

102. Cheng D, Li X, Zhang C, Tan H, Wang C, Pang L and Shi H: Detection of vulnerable atherosclerosis plaques with a dual-modal single-photon-emission computed tomography/magnetic resonance imaging probe targeting apoptotic macrophages. ACS Appl Mater Interfaces 7: 2847-2855, 2015.

103. Rahaman SO, Lennon DJ, Febbraio M, Podrez EA, Hazen SL and Silverstein RL: A CD36-dependent signaling cascade is necessary for macrophage foam cell formation. Cell Metab 4: 211-221, 2006

104. Versari D, Daghini E, Virdis A, Ghiadoni L and Taddei S: Endothelial dysfunction as a target for prevention of cardiovascular disease. Diabetes Care 32 (Suppl 2): S314-S321, 2009.

105. Medina-Leyte DJ, Domínguez-Pérez M, Mercado I, Villarreal-Molina MT and Jacobo-Albavera L: Use of human umbilical vein endothelial cells (HUVEC) as a model to study cardiovascular disease: A review. Applied Sciences 10: 938, 2020

106. Yang Q, Xu J, Ma Q, Liu Z, Sudhahar V, Cao Y, Wang L, Zeng X, Zhou Y, Zhang M, et al: PRKAA1/AMPKa1-driven glycolysis in endothelial cells exposed to disturbed flow protects against atherosclerosis. Nat Commun 9: 4667, 2018.

107. Chen Y, Liu R, Zhang G, Yu Q, Jia M, Zheng C, Wang Y, Xu C, Zhang Y and Liu E: Hypercysteinemia promotes atherosclerosis by reducing protein S-nitrosylation. Biomed Pharmacother 70: $253-259,2015$

108. O'Donnell J, Mille-Baker B and Laffan M: Human umbilica vein endothelial cells differ from other endothelial cells in failing to express ABO blood group antigens. J Vasc Res 37: 540-547, 2000.

109. Addis R, Campesi I, Fois M, Capobianco G, Dessole S, Fenu G, Montella A, Cattaneo MG, Vicentini LM and Franconi F: Human umbilical endothelial cells (HUVECs) have a sex: Characterisation of the phenotype of male and female cells. Biol Sex Differ 5: 18, 2014.
110. Crampton SP, Davis J and Hughes CC: Isolation of human umbilical vein endothelial cells (HUVEC). J Vis Exp 183 doi: 10.3791/183, 2007.

111. Jaffe EA, Nachman RL, Becker CG and Minick CR: Culture of human endothelial cells derived from umbilical veins. Identification by morphologic and immunologic criteria. J Clin Invest 52: 2745-2756, 1973.

112. Baudin B, Bruneel A, Bosselut N and Vaubourdolle M: A protocol for isolation and culture of human umbilical vein endothelial cells. Nat Protoc 2: 481-485, 2007.

113. Liu L and Shi GP: CD31: Beyond a marker for endothelial cells. Cardiovasc Res 94: 3-5, 2012.

114. Tabas I and Bornfeldt KE: Macrophage phenotype and function in different stages of atherosclerosis. Circ Res 118: 653-667, 2016.

115. Li AC and Glass CK: The macrophage foam cell as a target for therapeutic intervention. Nat Med 8: 1235-1242, 2002.

116. Zimmerman MA, Selzman CH, Reznikov LL, Miller SA, Raeburn CD, Emmick J, Meng X and Harken AH: Lack of TNF-alpha attenuates intimal hyperplasia after mouse carotid artery injury. Am J Physiol Regul Integr Comp Physiol 283: R505-R512, 2002

117. Zhang X, Goncalves R and Mosser DM: The isolation and characterization of murine macrophages. Curr Protoc Immunol Chapter 14: Unit 14 11, 2008.

118. Austyn JM and Gordon S: F4/80, a monoclonal antibody directed specifically against the mouse macrophage. Eur J Immunol 11: 805-815, 1981 .

119. Bennett MR and Boyle JJ: Apoptosis of vascular smooth muscle cells in atherosclerosis. Atherosclerosis 138: 3-9, 1998

120. Gao S, Xu L, Zhang Y, Yu Q, Li J, Guan H, Wang X, Cheng D, Liu Y, Bai L, et al: Salusin-alpha inhibits proliferation and migration of vascular smooth muscle cell via Akt/mTOR signaling. Cell Physiol Biochem 50: 1740-1753, 2018

121. Feng C, Wang X, Shi H, Yan Q, Zheng M, Li J, Zhang Q, Qin Y, Zhong Y, Mi J and Lai L: Generation of ApoE deficient dogs via combination of embryo injection of CRISPR/Cas9 with somatic cell nuclear transfer. J Genet Genomics 45: 47-50, 2018

122. Fang B, Ren X, Wang Y, Li Z, Zhao L, Zhang M, Li C, Zhang Z, Chen L, Li X, et al: Apolipoprotein E deficiency accelerates atherosclerosis development in miniature pigs. Dis Model Mech 11: dmm036632, 2018.

This work is licensed under a Creative Commons Attribution-NonCommercial-NoDerivatives 4.0 International (CC BY-NC-ND 4.0) License. 